\title{
Isolation of Protease Producing Bacteria from Soil for Polyester and Silver Recovery from Waste X-ray Film
}

\author{
Temam Abrar Hamza \\ Department of Biotechnology, College of Natural Sciences, Arba Minch University, Arba Minch, Ethiopia \\ Email address: \\ temam2abrar2@gmail.com

\section{To cite this article:} \\ Temam Abrar Hamza. Isolation of Protease Producing Bacteria from Soil for Polyester and Silver Recovery from Waste X-ray Film. \\ American Journal of BioScience. Vol. 5, No. 5, 2017, pp. 74-79. doi: 10.11648/j.ajbio.20170505.11
}

Received: June 10, 2017; Accepted: June 22, 2017; Published: August 30, 2017

\begin{abstract}
Proteases are multipurpose group of enzymes which mainly produced from microorganism and used in various industries such as detergent, silver recovery, food, pharmaceutical, leather and textile industries. This work aimed to isolate protease producing bacteria from local environment for use as silver recovery and reuse of polyester from waste X-ray film. Isolation of protease producer was undertaken using skim milk agar medium. A total of 36 protease positive bacteria were isolated from the study area (Arba Minch fish processing site). Five isolates were screened which had relatively higher clear zone and further examined gelatin removal efficiency of their crude enzymes. One isolate designated as Bacillus sp. THZ14 was selected on the basis of gelatin removal efficiency. The crude enzyme from this strain removed gelatin on waste X-ray film at $\mathrm{pH} 9,40^{\circ} \mathrm{C}$ in $40 \mathrm{~min}$. These properties suggest that protease from Bacillus $s p$. THZ14 could find potential application in silver recovery process and reuse of polyester sheet which have an economic implication.
\end{abstract}

Keywords: Bacillus sp. THZ14, Enzyme, Gelatin Hydrolysis, Protease, X-ray Films

\section{Introduction}

Almost All form of life (animal, plant and microbes) on earth constituent's protease enzyme for their physiological function. Microbes are ubiquitous and live in familiar setting such as Soil, water, food, and animal intestines, as well as in more extreme setting such as rocks, glaciers, hot springs, and deep-sea vents. The beneficial microbes are fascinating, versatile and carry out extremely useful processes that can't be achieved by other physical and chemical means. Proteolytic enzymes from microbial sources are preferred over the enzymes derived from plant and animals due to their susceptibility for genetic manipulation [1]. Currently, microbial proteases represent one of the largest groups of industrial enzymes and account for approximately $60 \%$ of the total industrial enzyme sale in the world.

Microbial proteases are one of the most important groups of enzymes, used in various industrial processes as food, pharmaceutical and detergent industries, as well as in the preparation of leather, textile and wool, among others $[2,3,4$, 5]. It has also promising application in medical usage and management of industrial and household waste. The use of microbial system (enzymes) is the best alternative for generation of pollution free industries [6].

Recovery of silver and polyester sheet from waste X-ray film is possible through biological treatment. The conventional method for recovery of silver is burning and chemical treatment of the films directly. This generates undesirable foul smell and environmental pollution. In addition polyester film on which emulsion of silver and gelatin is coated cannot be recovered. Microbial proteases are being used as best alternatives to the burning and chemical methods of silver recovery from waste X-ray films. This not only helps in extracting silver, but also the polyester film base can be recycled [7, 8, 9]. Microbial protease has a significant potential for hydrolysis of gelatin layer and as result releases silver from waste photographic film $[10,11$, 12]. Bearing in mind this critical factor, effort should be directed to search microorganisms which produce proteases with high stability in the environment of silver recovery process. These all contribute toward the idea of clean technology and environmentally friendly approach for the welfare human being.

Considering these vital and unlimited industrial applications of microbial product, there is a need to effort by investigating new microorganisms because they are the major 
sources of all commercially important enzymes. In this regard, microorganisms have still potential to produce enzymes, even though production cost of the enzyme is the critical issue.

In fact, Ethiopia have broad microbial diversity, however protease producing bacteria for silver recovery have not yet been explored. Therefore a research project has been initiated with the objectives of isolating protease producing bacteria from local environment for silver recovery and reuse of polyester from waste $\mathrm{x}$-ray sheet.

\section{Materials and Methods}

\subsection{Sample Collection and Isolation of Proteolytic Bacteria}

Soil samples were collected from fish processing area (Southern Nation Nationalities of people Region, Gamo Gofa Zone, Arba Minch). Each sample was kept in clean sterile sample bottles sealed and transferred to the laboratory and stored at $7^{\circ} \mathrm{C}$.

The soil samples were suspended in water by vigorous vortexing and serial dilutions were made and appropriate dilution were spread on skim milk agar plate containing peptone $(0.1 \%), \mathrm{NaCl}(0.5 \%)$, Agar $(2 \%)$ and skimmed milk $(10 \%)$ at $\mathrm{pH} 9$ and incubated at $40^{\circ} \mathrm{C}$ for three days. Clear zone forming (proteolytic) bacteria were screened and purified by streaking on skim milk agar. The cultures were subsequently sub-cultured and used regularly.

\subsection{Screening of Potential Isolate}

The potential bacterial strains were screened for the quality of enzyme produced under submerged condition. The supernatant from each isolate was used as crude enzyme for observing individual for gelatin hydrolysis performance. Single potential strain was select on the basis of gelatin removal efficiency from used X-ray sheet. Identification of the selected potential isolate was performed according to Bergey's manual of determinative bacteriology [13].

\subsection{Morphological Characterization}

Potential isolate was characterized by colony (shape, size, elevation, colour, margin and configuration); cell (Gram stain, determination of the presence of spore).

\subsection{Biochemical Characterization}

Potential isolates were characterized by different biochemical methods catalase test, citrate utilization test and MR-VP test.

\subsection{Enzyme Activity}

Protease production media was prepared according to the method described by Das and Prasad, 2010) [14]. The pH of the medium was adjusted to 9 and bacterial isolate was inoculated with $1 \%$ of inoculum into $100 \mathrm{ml}$ production medium followed by incubation at $40^{\circ} \mathrm{C}$ for 48 hours in water bath shaker at $150 \mathrm{rpm}$. Culture filtrates were used as crude enzyme source for quantitative enzyme assay. Protease activity in the culture supernatant was determined using casein as a substrate with some modification of the method described by Gaur et al. (2010) [15]. The enzyme activity was expressed in units (U) and calculated by using tyrosine standard calibration curve. One unit of enzyme was defined as the amount of enzyme that releases $1 \mu \mathrm{mol}$ of tyrosine per $\mathrm{ml}$ of crude extract per minute under standard conditions at $40^{\circ} \mathrm{C}$.

\subsection{Recovery of Silver and Reuse of Waste X-ray Film}

Removal of gelatinous coating from used X-ray film: Removal of gelatin from used X-Ray film was done as described in Shankar et al. (2010) [16] with some modification. Used X-ray films $(0.213 \mathrm{~g}$ each $)$ were washed with distilled water and wiped with cotton impregnated with ethanol. The washed film was dried in oven at $40^{\circ} \mathrm{C}$ for 30 min. X-ray film (2 $\times 3 \mathrm{~cm}$ pieces) was incubated with $20 \mathrm{ml}$ of crude enzyme (film completely immersed in solution) at $40^{\circ} \mathrm{C}$ with continuous shaking at $150 \mathrm{rpm}$ until complete removal of gelatin from films. Optimum $\mathrm{pH}$ for hydrolysis of gelatin was determined at $40^{\circ} \mathrm{C}$ and $\mathrm{pH}$ from 7.0 to 12.0 .

Weight loss of X-ray film: Weight loss of the film was analyzed by measuring the weight of used X-ray film before and after complete removal of gelatin layer.

Reuse of enzyme for hydrolysis: Reuse of enzyme for gelatin hydrolysis was evaluated at $40^{\circ} \mathrm{C}, \mathrm{pH} 9$ and $150 \mathrm{rpm}$ in a rotary shaker with continuous shaking until the gelatin layer was completely removed. After complete removal of gelatin, a new film was incubated in the reaction mixture up to six turns.

Recovery and detection of silver: The presence of silver in the reaction slurry was confirmed by nitric acid test [12]. After complete gelatin removal, reaction slurry was digested with nitric acid and analyzed by Atomic Absorption Spectrophotometer at wavelength of $328.1 \mathrm{~nm}$. The concentration of silver metal was determined by using generated silver standard curve with regression coefficient of $\mathrm{R}^{2}=0.9935$.

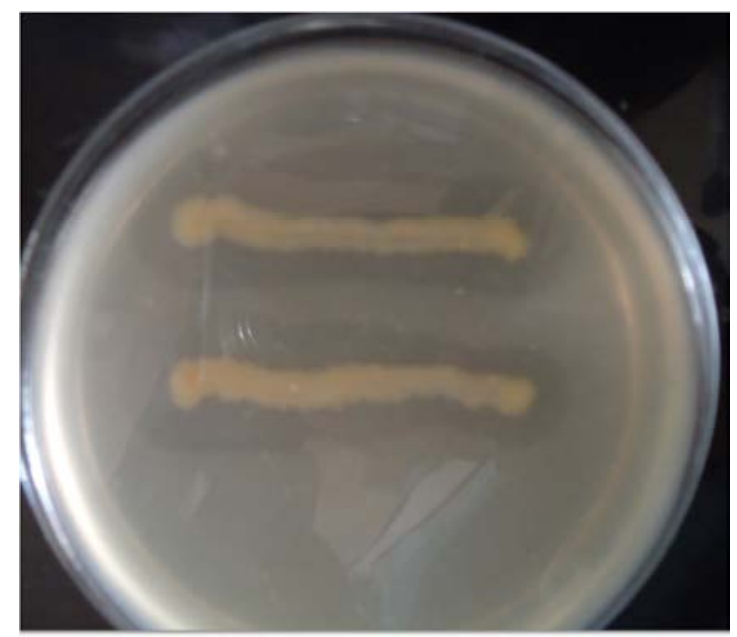

Figure 1. Zone of hydrolysis by strain C14 in milk agar plate after $18 \mathrm{~h}$ incubation at $40^{\circ} \mathrm{C}$. 


\subsection{Data Analysis}

Average values of duplicate experiments were taken. Microsoft office Excel worksheet 2010 was used for data analysis and presentation.

\section{Results}

\section{Isolation of Proteolytic Bacteria}

Thirty six protease positive isolates were obtained from the study area. Hence the strains were identified as a protease producer since the formation of clear zone around the colony due to hydrolysis of skimmed milk protein in the medium (Figure 1). Out of 36 protease positive bacterial isolates, 5 isolates with relatively higher clear zones were further examined.

Selection of Potential Isolate

The five isolates were compared for gelatin removal efficiency with respect to time and isolate $\mathrm{C} 14$ was selected for further study. The results are summarized in Table 1.

Table 1. Results of gelatin removal efficiency of five selected isolates at $p H 8$.

\begin{tabular}{|c|c|c|c|}
\hline S. No & Strain code & Gelatin hydrolysis ability from used x-ray & Time taken (Minute) \\
\hline 0 & Control & & - \\
\hline 1 & $\mathrm{C} 5$ & & 70 \\
\hline 2 & $\mathrm{C} 10$ & & 120 \\
\hline 3 & $\mathrm{C} 16$ & & 80 \\
\hline 4 & $\mathrm{C} 33$ & & 120 \\
\hline 5 & C14 & & 45 \\
\hline
\end{tabular}

\section{Morphological and Biochemical Characteristics of Isolate} C14.

Table 2 and Figure 2 show results of morphological and biochemical tests of the selected isolate. Motile, long irregular and rod shaped cells were observed under light microscope. Based on this the isolate was designated as Bacillus sp. THZ14.

Table 2. Results of the morphological and biochemical tests of isolate C14.

\begin{tabular}{llll}
\hline Morphological characteristics & Results & Biochemical characteristics & Results \\
\hline Colour & Creamy white & Nitrate reduction & Negative \\
Size & Large & Indole tests & Positive \\
Margin & Irregular & MR-VP test & Negative \\
Elevation & Flat & Citrate utilization & Negative \\
Configuration & Irregular and spread & Casein hydrolysis & Positive \\
Morphology & Rod & & \\
Gram reaction & Positive & & \\
Endospore & Elliptical & & \\
Motility test & positive & & \\
\hline
\end{tabular}



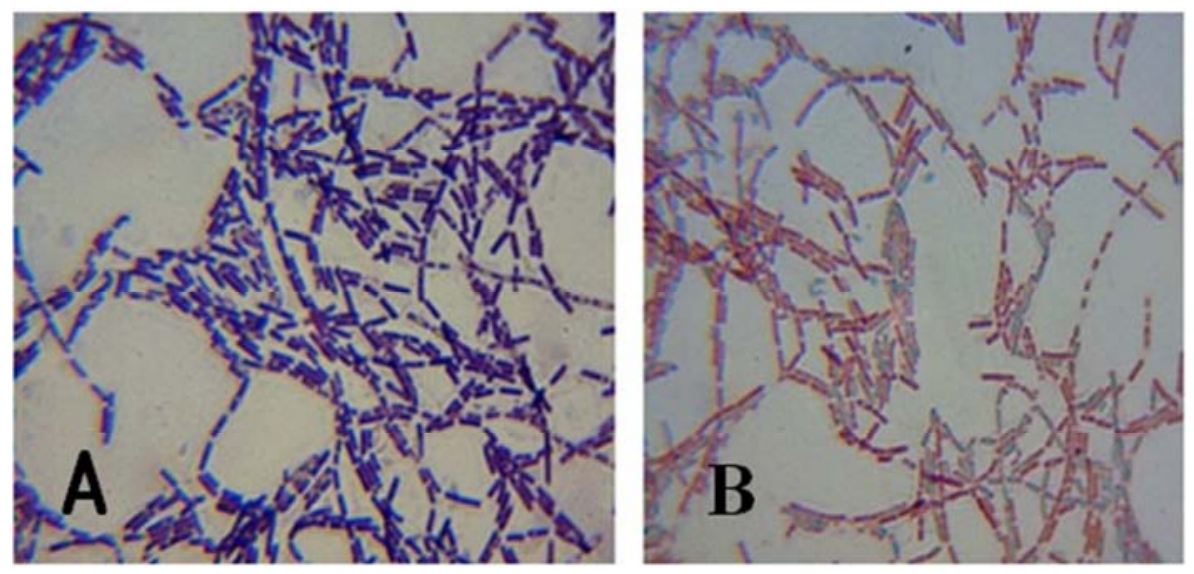

Figure 2. Gram reaction result (+ve) (a) and Endospore of Bacillus sp. THZ14 (b) at $40^{\circ} \mathrm{C}$ and $24 \mathrm{~h}$ on milk agar.

Silver and Polyester Recovery from Waste X-ray Film Sheet

Effect of pH on Gelatin Hydrolysis

Gelatin removal was observed over a $\mathrm{pH}$ range of 7 to 10 with maximum hydrolysis at $\mathrm{pH} 8$ and 9. Complete gelatin removal was observed within 40 min at $\mathrm{pH} 9$ (See Figure 3).

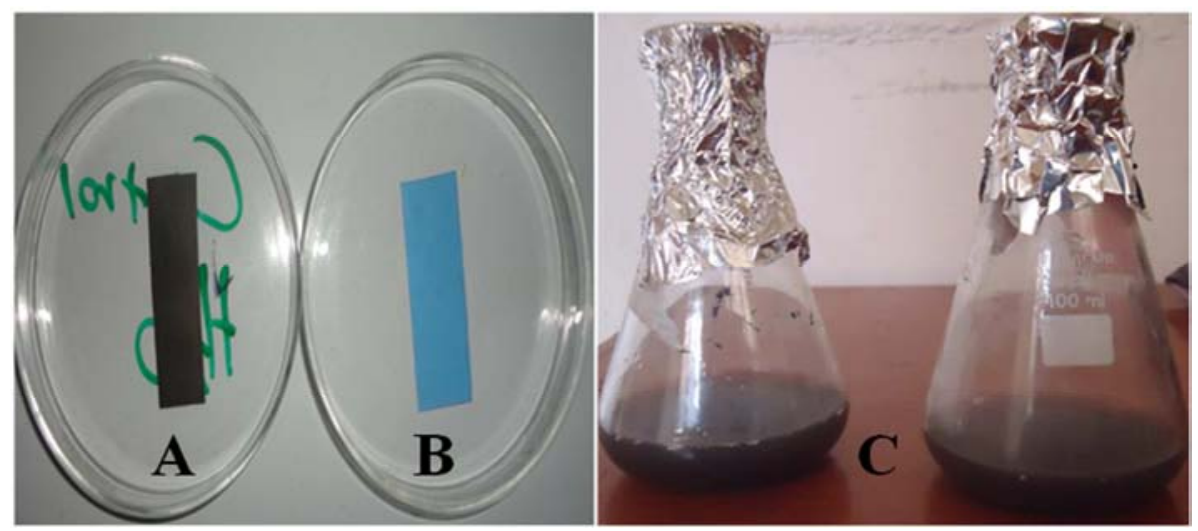

Figure 3. Hydrolysis of used X-ray film by crude enzyme produced from Bacillus sp. THZ14. Sample pictures: (A) control (20ml of Bicarbonate buffer) and (B) gelatin layer removal from the film after 40 min incubation at $40^{\circ} \mathrm{C}$ and $\mathrm{pH} 9$ with crude enzyme. (C) Reaction slurry after $5^{\text {th }}$ cycle of gelatin removal.

The hydrolytic efficiency of the enzyme increased from $\mathrm{pH} 7$ to 9 and declined above $\mathrm{pH} 9$ (Figure 4). Desired hydrolysis was observed at $\mathrm{pH}$ ranges from 8.0-10.0. Turbidity of the reaction mixture was compared with respect to their $\mathrm{pH}$ after 20 minute incubation.

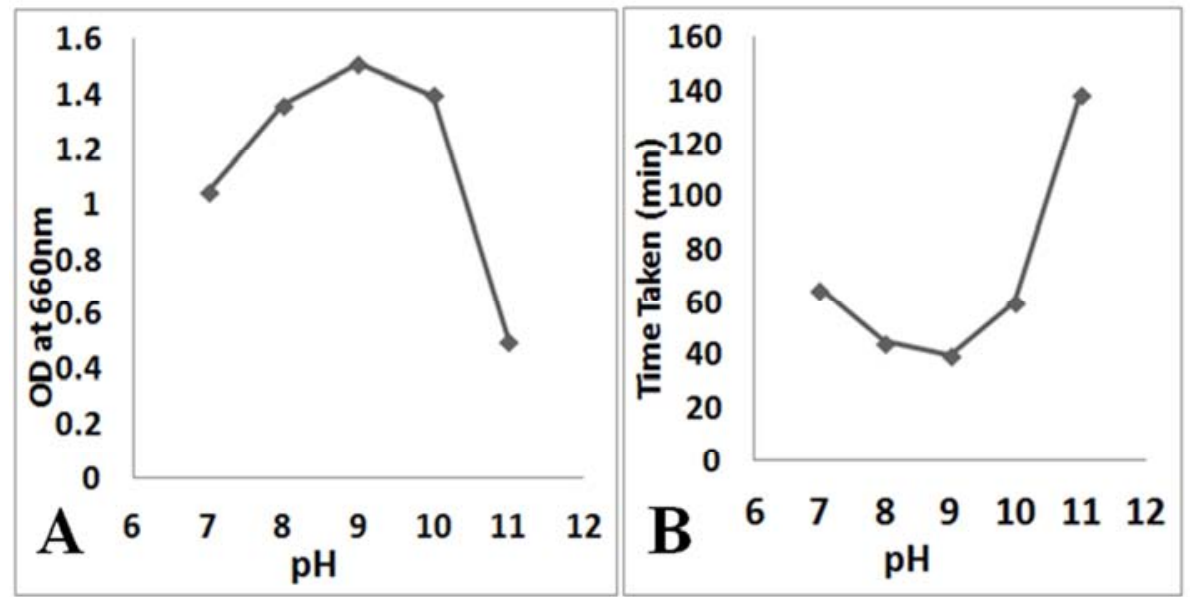

Figure 4. Effect of $\mathrm{pH}$ on gelatin hydrolysis with crude enzyme at $\mathrm{pH} 7-11,150 \mathrm{rpm}$ and $40^{\circ} \mathrm{C}$ (A) Optical density of the reaction slurry after 20 min incubation (B) Time course for complete gelatin removal. 


\section{Reusability of Enzyme for Gelatin Hydrolysis}

The crude enzyme removed gelatin from used X-ray films for 4 successive cycles in comparable time intervals. The removal took excessive time after the fourth cycle (Table 3).

Table 3. Reusability of the enzyme at $40^{\circ} \mathrm{C}$.

\begin{tabular}{llllll}
\hline Cycle & $\mathbf{1}$ & $\mathbf{2}$ & $\mathbf{3}$ & $\mathbf{4}$ & $\mathbf{5}$ \\
\hline Time for complete removal (min) & 40 & 54 & 65 & 119 & Take excessive time \\
\hline
\end{tabular}

Weight Loss of Used X-Ray Film after Gelatin Removal.

Used X-ray films were treated with crude enzyme and resulted in stripping off the sliver bound with gelatin into the reaction mixture and clean plastic film was recovered (Figure 3 ). As a result, weight loss of the film was noticed after cleaning the used X-ray film. The average weight of the Xray film before incubation was $0.213 \mathrm{~g}(2 \mathrm{~cm} \mathrm{x} 3 \mathrm{~cm})$. After gelatin and other components of the film were removed, the weight of the film became $0.201 \mathrm{~g}$. Therefore, the weight loss was calculated as $0.012 \mathrm{~g}$. The value indicates that $5.6 \%$ of the film weight was lost after the film was treated with crude enzyme.

Recovery and Detection of Silver

The presence of silver in the slurry was detected by nitric acid test. The result of the nitric acid test is shown in Figure 5. It was confirmed by atomic absorption spectrophotometry and the concentration determined as $0.042 \mathrm{M}$.
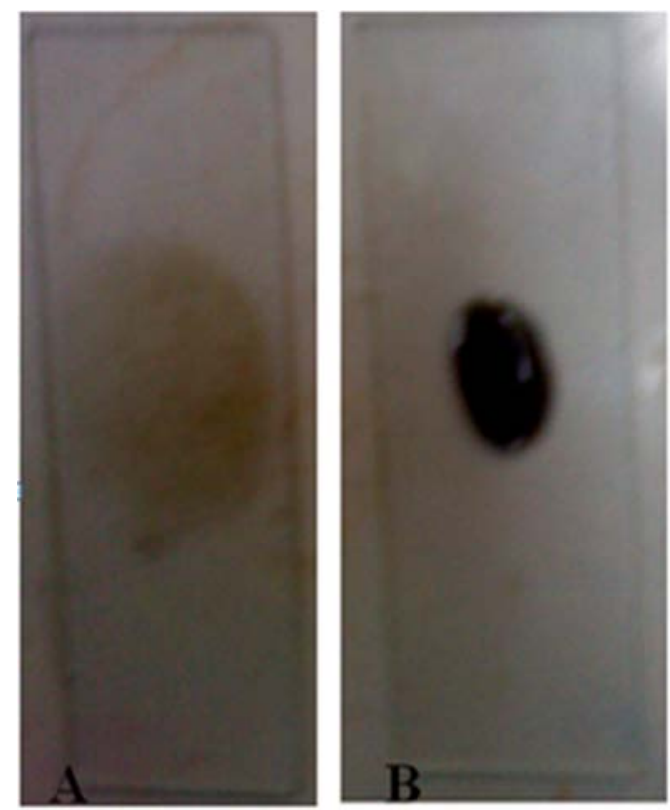

Figure 5. Nitric acid test (reaction slurry with a drop of nitric acid (A); Control (B).

\section{Discussion}

Isolation and identification of bacteria which have vital ability to secret extracellular protease enzyme to be used for silver recovery and reuse of polyester from waste X-ray film is one of the main concerns of this study. Accordingly, 36 bacterial strains were isolated from study area. Formation of clear zone around the bacterial colony indicated the protease positive strains hydrolysed the skim milk present in the media (Figure 1). The use of skim milk agar medium for the isolation of protease producing bacteria has earlier been reported by some workers $[17,18,19]$.

Five isolates had larger clear zone are screened. Out of these isolates, Bacillus sp. THZ14 exhibited high capability of removing gelatin from used X-ray films within short period of time when compared to others (Table 1).

As shown in Figure 3 and 4, used X-Ray films treated with protease produced from Bacillus sp. THZ14 resulted in the silver bound with gelatin being stripped off in to the reaction mixture after $40 \mathrm{~min}$ at $\mathrm{pH}(9)$ and $40^{\circ} \mathrm{C}$. On the other hand, no gelatin removal was also observed at all when the experiment was conducted without incorporation of enzyme in the reaction mixture (Bicarbonate buffer only at $\mathrm{pH}$ of 9) at $40^{\circ} \mathrm{C}$ for $40 \mathrm{~min}$. This implies protease produced in the present study has appreciable application in the process of silver recovery and reuse of polyester from used X-ray film. Similar results were reported by some researchers $[8,9,11$, 12].

Colour change was observed when a drop of nitric acid was added into the reaction slurry (Figure 5). The presence of silver in the mixture was confirmed by the color change observed. Similar finding was reported [12]. The concentration of silver found in the mixture was $0.042 \mathrm{M}$. This implies that it is possible to recover silver from used $\mathrm{X}$ ray film using the protease produced from Bacillus $s p$. THZ14. Similar result was reported by Shankar et al. (2010) [16].

Gelatin removal efficiency of the enzyme required relatively the same time up to the fifth cycle and required more time at the $5^{\text {th }}$ cycle reuse. This shows the reusability of the produced enzyme. Masui et al. (1999) [9] reported that a protease spent $60 \mathrm{~min}$ and $>120 \mathrm{~min}$ for removal of gelatin from used X-ray film in the $1^{\text {st }}$ and $2^{\text {nd }}$ cycles, respectively at $50^{\circ} \mathrm{C}$. Hence, comparing the experiment conducted in this study, which requires $40 \mathrm{~min}$ and $54 \mathrm{~min}$ to remove gelatin in the $1^{\text {st }}$ and $2^{\text {nd }}$ cycle (Table 3 ), respectively the present enzyme saves approximately two and four fold time for the same process, respectively. This indicates that, the enzyme produced by Bacillus sp. THZ14 is good candidate for silver recovery and reuse of polyester from used X-ray film.

When the X-ray films treated with crude enzyme for about $30 \mathrm{~min}$ and the result indicates that used X-ray film could loss its weight by $5.6 \%$ based on initial weight of the film. Results are almost similar with that investigated by Shankar et al. (2010) [16] and loss in weight after enzyme treatment was around $5 \%(\mathrm{w} / \mathrm{w})$.

In general the use of microorganisms to produce enzymes has a number of technical and economic advantages and in 
recent years it has become the predominant mode of enzyme production [20]. The exploration of protease producing bacteria is still underway to achieve high quality industrial grade enzyme to produce goods [21].

\section{Conclusions}

As the method described in this investigation for removal of gelatin from used X-ray film undergoes the process without any additive of hazardous chemicals, it would have minimum impact on the environment as compared to conventional chemical and burning methods. The recovered pure polyester film after gelatin removal can also be reused that helps minimize the production of large number of polyester films. Further, silver is one of the precious metals, so recovering it from the film will have economic implication.

\section{Acknowledgements}

The author wish to thank Ato Zerihun Senbeto for his financial support for publication of this research paper. Also the author would like to thank to Belist Lelisa, Abebe Bashe, Nigatu Eligo, and Teshome Gudeta for their technical supports. Last but not least, author would like to thank to Nuredin Nassir and Awel Abdella for their major comments.

\section{References}

[1] Padmapriya, B., Rajeswari, T., Nandran, R. and Raj, F. (2012). Production and purification of alkaline serine protease from marine Bacillus species and its application in detergent industry. European Journal of Applied Sciences, 4:21-26.

[2] Gupta, R., Beg, Q. K. and Lorenz, P. (2002). Bacterial alkaline proteases: molecular approaches and industrial applications. Applied Microbial Biotechnology, 59:15-32.

[3] Saha, M. L., Begum, K. J. M. H., Khan, M. R. and Gomes, D. J. (2011). Bacteria associated with the tannery effluent and their alkaline protease activities. Plant Tissue Culture Biotechnology, 21:53-61.

[4] Younes, G., Sara, R., Alireza, E., Aboozar, K., Maryam, S. and Najme, T. (2011). Screening and isolation of extracellular protease producing bacteria from the Maharloo Salt Lake. Iranian Journal of Pharmaceutical Sciences, 7:175-180.

[5] Vadlamani, S. and Parcha, S. R. (2011). Studies on industrially important alkaline protease production from locally isolated superior microbial strain from soil microorganisms. International Journal of Biotechnology Applications, 3:102105.

[6] Saperas, N. and Subir, F. E. (2011). Proteolytic enzymes in detergents: evidence of their presence through activity measurements based on electrophoresis. Journal of Chemistry, 88:1702-1706.

[7] Kumara, C. G. and Takagi, H. (1999). Microbial alkaline proteases: From bioindustrial viewpoint. Biotechnology Advances, 17:561-594.
[8] Pathak, A. P. and Deshmukh, K. B. (2012). Alkaline protease production, extraction and characterization from alkaliphilic Bacillus licheniformis KBDL4: A Lonar Soda Lake isolate. Indian Journal of Experimental Biology, 50:569-576.

[9] Masui, A., Fujiwara, N., Takagi, M. and Imanaka, T. (1999). Feasibility study for decomposition of gelatin layers on X-ray films by thermostable alkaline protease from alkaliphilic Bacillus sp. Biotechnological Techniques, 13:813-815.

[10] Chaudhari, S. G., Chaudhari, S. D., Khobragade, R. M. and Deshmukh, A. M. (2013). Studies on production of alkaline proteases from Bacillus species and its application in detergent industry. Dav International Journal of Science, $2: 44-48$.

[11] Nakiboglu, N., Toscali, D. and Yasa, I. (2001). Silver recovery from waste photographic films by an enzymatic method. Turkish Journal of Chemistry, 25:349-353.

[12] Annapurna, S. A., Singh, A., Garg, S., Kumar, A. and Kumar, H. (2012). Screening, isolation and characterisation of protease producing moderately halophilic microorganisms. Asian Journal of Microbiology, Biotechnology and Environmental Science, 14:603-612.

[13] Bergey, D. H. and Holt, J. G. (1994). Bergey's manual of determinative bacteriology, $9^{\text {th }}$ edition Williams and Wilkins, Baltimore.

[14] Das, G. and Prasad, M. P. (2010). Isolation, purification \& mass production of protease enzyme from Bacillus subtilis. International Research Journals of Microbiology, 1:26-31.

[15] Gaur, S., Agrahari, S. and Wadhwa, N. (2010). Purification of protease from Pseudomonas thermaerum GW1 isolated from poultry waste site. The Open Microbiology Journal, 4:67-74.

[16] Shankar, S., More, S. V. and Seeta, L. R. (2010). Recovery of silver from waste $\mathrm{x}$-ray film by alkaline protease from Conidiobolus coronatus. Kathmandu University Journal of Science, Engineering and Technology, 6:60-69.

[17] Haile, G. and Gessesse, A. (2012). Properties of alkaline protease $\mathrm{C} 45$ produced by alkaliphilic Bacillus $s p$. isolated from Chitu, Ethiopian Soda Lake. Journal of Biotechnology and Biomatter, 2:1-4.

[18] Boominadhan, U., Rajakumar, R., Karrpaga, P. V. S. and Joe, M. M. (2009). Optimization of protease enzyme production using Bacillus sp. Isolated from different wastes. Botany Research International, 2:83-87.

[19] Harish R. and Chauhan, B. J. (2017). Isolation, characterization of protease producing microbes from soil of agriculture land and purification of protease. International Journal of Pharma Research and Health Sciences, 5 (1):15811585 .

[20] Singh, P., Rani, A. and Chaudhary, N. (2015). Isolation and characterization of protease producing Bacillus sp from soil. International Journal of Pharma Sciences and Research, 6(4):633-639.

[21] Priya, V. V. G., Preethi, S., Karthikeyan, S. and Babu, R. N. G. (2016). Isolation and identification of protease producing bacteria from soil. International Journal of Research in Engineering and Technology, 3(8):1362-1365. 